Article

\title{
Behind the Battle Lines of History as Politics: An International and Intergenerational Methodology for Testing the Social Identity Thesis of History Education
}

\section{Tony Taylor * and Sue Collins}

Faculty of Education, Monash University, Northways Rd, Churchill, Vic 3842, Australia; E-Mail: sue.collins@monash.edu

* Author to whom correspondence should be addressed; E-Mail: Tony.Taylor@monash.edu; Tel.: +61-03-5122-6365; Fax: +61-03-5122-6361.

Received: 8 November 2012 / Accepted: 21 November 2012 / Published: 23 November 2012

\begin{abstract}
This article critiques popular assumptions that underlie the ongoing politicisation of school history curriculum as an agent of social identity and behaviour. It raises some key research questions which need further investigation and suggests a potential methodology for establishing evidence-based understanding of the relationship between history education, historical consciousness, identity politics and civil discord. The proposed methodology is based on comparative research of the lived experience of history education and social disposition in two generations in three modern democratic nations each of which represent in their recent histories different models of social integration. The article suggests that without such evidence-based theorisation of the relationship between historical consciousness and social identity, the evolution of history curricula will remain vulnerable to the ongoing incursions of hostile but poorly conceived political rhetoric.
\end{abstract}

Keywords: history education; social identity; historical consciousness 


\section{Introduction}

On Sunday 16 September 2012, public protests by members of the Islamic community against the release of a low-budget U.S.-made film that overtly demeaned the Prophet Mohammed and the Islamic religion occurred in central Sydney; protests also took place around the world in many other cities with significant Islamic populations. Six Sydney police officers were injured and the evident readiness of some demonstrators to advocate violent retribution in defending Islam, including providing Islamic children with banners calling for murder, was exceptional and intimidatory [1]. Media outrage and calls for calm came from both Islamic and non-Islamic representatives.

The following day, on 17 September 2012, an article appeared in the national broadsheet newspaper, The Australian, with the headline "Counter Islamism with Commitment to Core Values" [2]. The writer of the article was the paper's principal conservative commentator on education reform, particularly in relation to history education, Kevin Donnelly. While Donnelly's position was neither new nor unexpected, the fact that the national paper chose to respond to the events of the weekend with an immediate recourse to reinforcing standard conservative criticism of the failings of "progressive" school history curricula is a key point of interest in this paper.

Best represented by the ALP-inspired national curriculum, the prevailing cultural-left orthodox in school curriculums is one that celebrates difference and diversity instead of the meta-narrative associated with the rise of Western civilization and the debt we owe to liberal, democratic values and Australia's Judeo-Christian heritage.

Earlier copies of the draft history curriculum ignored the importance of documents such as the Magna Carta and the final edition ignores the significance and contribution of Christianity to our institutions and way of life by treating it superficially and describing it as only one religious faith among many. [2]

While his characterisation of the new Australian Curriculum in History and current teaching of school history in general is questionable on all fronts, Donnelly's position neatly summarises the assertions which are repeated in almost identical form in most conservative political commentary on the new curriculum. Also stereotypically, Donnelly deplores the prevalence of "postmodern" influence in educational philosophy and practice, which he claims takes the dangerous position that "all cultures are of equal value and worth". Suggested potential counter-influences to the alleged tendency of postmodernist moral relativism to produce a destructive and "self-centred" population are flag-raising ceremonies and singing the national anthem in schools [2].

Given that the Islamic protestors of most concern in the Sydney riots are themselves the products of a fundamentalist minority of the Islamic community that adheres to its own more spectacular forms of jingoism ("Our dead are in paradise, your dead are in hell” [1]), a simple, traditional, weekly school-yard flag-raising ceremony, presumably with its traditional accompaniment of puzzled boredom, elbowing and shoe-scuffling, would be hard pressed to compete in terms of social imprinting. This model of response, if it is the only one available to be resorted to in a modern multicultural society, does not bode well for any possible future in which the relationship between group identity education and social behavior might be better understood and more effectively handled by our social institutions. 
History education in modern, mass education systems is commonly regarded by politicians, media commentators and educators alike as a major factor in the construction of particular forms of historical consciousness that provide the basis for social disposition and social action.

Historical consciousness is defined as the process by which accounts of certain events and narratives enter, are denied entry and/or are modulated as they enter into collective memory at the level of school history, public history, family stories, media representations as well as ideological and community narratives (adapted from [3]). However, when we discuss the factors that play a part in the development of historical consciousness we shall see that there are questions hanging over the politically-based assumption that prescribed forms of history in schools lead to prescribed outcomes in attitudes and behaviours.

In this article we outline some of the issues involved in a long-standing dilemma concerning the relationship between history education and social action and we propose a set of research questions and a methodology based on three illustrative case studies to form the basis of evidence for theorisation of this relationship.

\section{The Background}

While most democratic governments of all kinds take a functionalist and economically-based interest in literacy and numeracy, many are quick to take an active, ideologically-based interest in history education. Assumptions about the contribution of school-level history education to historical consciousness and to consequent social group behaviours are expressed in the ongoing political, media, academic and public attention given to the teaching of history as an important factor in engineering social cohesion or social division [4]. However, there is currently no substantive evidence that these assumptions about the societal impact of history education in modern democracies are warranted. While there is plenty of political and media energy spent on the issue, any significant evidence of the impact of history education on social behavior in modern democracies has yet to be established.

Indeed, in scholarly histories of the three western democracies of interest here, there is little if any mention of the influence of school history education on social/political disposition, behaviour or events [5-7]. History education also goes unmentioned amongst key historical sociologists who have, in particular, investigated the factors that lead to civil disorder and conflict [8-10]. Furthermore, significant findings by U.S. researchers Rosenweig and Thelen [11] as well as by Australian researchers Ashton and Hamilton [12] seem to contradict these assumptions about the importance of history education in shaping either conservative or progressive forms of sustained historical consciousness in populations at large. Instead, research findings appear to show that the impact of history education, whether traditionalist or progressive, is not lasting and is not directly linked to social action.

In order to test popular assumptions about the power of history education as politically formative it will therefore be necessary to know more about the role that history education has actually played in fostering social discord and/or cohesion in modern multicultural democratic societies.

In this article we suggest a methodology involving an examination of the political contexts of history education over two generations in three representative multicultural western democracies that have experienced varying forms of historically-framed social trauma and disruption; these democracies 
are Argentina, Northern Ireland (NI) and Australia. Drawing upon the work of Maria Paula Gonzalez in Argentina, Alan McCully in Northern Ireland and Paul Ashton and Paula Hamilton in Australia, we propose the following questions as a potentially fruitful research model:

- what was the past state of the relationship between history education, historical consciousness, identity politics and civil discord in all three countries during periods when each country faced diverse kinds of civil turbulence?

- what is the current state of the relationship between progressive history education, historical consciousness, identity politics and civil discord in all three countries as each country attempts to face up to old and new social challenges?

- what can the consideration of these questions contribute to globally significant understandings regarding the role of history education in a civil society?

The basis for this proposed use of case studies comes from preliminary findings by Northern Irish researchers Reilly and McCully which suggest that conventional history education, which generally has a focus on cognition, is overwhelmed in terms of its impact by the influence of affect on individual disposition and action. As it happens, such affective learnings about the past are fuelled more by political, family and community memories as well as by national and local commemorations $[13,14]$.

To complicate matters, the recent work of Dutch academic Maria Grever and her European colleagues suggests that there are previously unacknowledged complexities and paradoxes within progressive history education provision in multicultural societies [15-17]. These emerging complexities provide a strong indication that ideologically-inspired interventions in history curriculum are likely to be counter-productive at best and socially disruptive at worst, whether generated by conservative or by liberal forces.

The broader background to this overarching issue of history education's actual effect lies in the social conflicts that continue to afflict western nations struggling to deal with the modern politics of multiculturalism and the persistent recourse by politicians and social commentators to past events as active elements in the rhetoric of culturally-divisive politics [4]. Further, we are currently witnessing postcolonial adjustments to the realities of renewed religio-political ambitions amongst adherents to varieties of beliefs. For example, Margaret MacMillan provides a lucid discussion of Hindu nationalism and its attempts to obliterate the Muslim contribution to Indian society, a phenomenon that is apparent in many postcolonial societies where benign aspects of an imperial past or the contribution of repressed minorities to a national narrative are discounted in official histories [18]. Other adjustments include the political consequences of the break-up of the former Soviet Union [19], the more recent global turbulence caused by jihadist and non-jihadist Islamic intentions [20], the growing intensity of the rhetoric of social fragmentation observed in western democracies during times of mass, cross-border movement of peoples and the consequent globalisation of domestic intercultural tensions.

These phenomena highlight the need for an investigation into the contexts, the relative relationships and the actual effects within any given democratic society of the dissemination of history in schools when evidence suggests that public narratives and informal, community and family narratives have played, and continue to play, a more central part than history education in the dynamics of identity-related civil discord. 
The significance of investigating these issues lies in a potential set of findings that could militate against a globally-prevalent tendency towards ill-informed, educationally unsound and emotionally-derived political interference in history curricula. Indeed, the past 30 years have witnessed increasing levels of political intervention in history education curriculum. For example, the Thatcher administration, Ronald Reagan's administration, the Howard government and now Russia's Putinist regime have all been involved in politicised interference in history curriculum. Even in a customarily progressive Netherlands, the government of rightist former Prime Minister Jan Pieter Balkenende, anxious about the perceived dilution of Dutch national character following a period of mass migration from Surinam and Morocco, introduced an optional 50-point essentialist 'canon' of Dutch historical events into the school curriculum in 2006 that became compulsory for Years 4-10 in August 2009 [21]. Evidence-based theorisation of the relationship between history education and social identity would provide a more rational and stable basis for curriculum design in the face of these kinds of political pressures.

\section{Why These Three Case Studies: Argentina, Northern Ireland and Australia?}

Each of these three illustrative national stories, posited as case studies for the purposes of this article, is situated within a different socio-cultural framework. These frameworks are: assimilationist (Argentina,) separatist (Northern Ireland) and integrationist (Australia) [22]. To briefly define these: Argentina was, prior to 1983, an assimilationist society operating according to the values of a dominant tradition with minority rights and interests neglected; Northern Ireland (NI) was (and is to some extent) a separatist society serving different homogeneous constituencies; Australia (post 1972) is an avowedly multicultural society that shares common goals within a diverse population.

In addition, the three countries in question provide a sample of social discord categories on a continuum that ranges from the imposition of state terror (Argentina), through violent internecine civil conflict (NI) to largely peaceful social protest and division (Australia). This provides an overview of the role of history education in forming historical consciousness in a way that affects social and political attitudes within three varied political systems that have, within living memory, encountered different models of historically-shaped, fateful social and political crises.

The question here would be, therefore, how did forms of history teaching affect the creation of historical consciousness prior to and during turbulent times in, for example, the background to the imposition of state terror in Argentina 1976-1983, the origins of the latest outbreak of civil disorder, the 'Troubles', in Northern Ireland 1969-1998 and highly controversial divergences of political and social opinion in Australia 1969-1975?

\section{Three Case Studies: The Importance of Context}

\subsection{Argentina}

Prior to the period of the 1976-83 military junta, history education in Argentina was constructed on the late 19th century notion of patriotic history, concerned with the post-colonial origins of the nation. Assimilationist, patriarchal, identity-based and mythic narratives predominated in which the diverse peoples of Argentina were subsumed into a homogenised whole [23]. A 'national biography' of 
Argentina was developed, the main aim of which was to accentuate heroic post-colonial achievements, acculturate migrant groups and develop a single notion of a model citizen [24]. What we do not know is how the citizens of Argentina, including the ideologically marginalised, viewed the contribution of their own historical education when it came to their political and social sensibilities and activities prior to the military coup of 1976 and during the period of the junta. At this time school history was redirected to focus on increasingly assimilationist pro-Catholic and anti-Marxist directions combined with the kinds of strong nationalist sentiment that led, for example, to the generals' invasion of the Malvinas/Falklands in 1982. Following a post-junta period of educational reform based on a reformist Spanish model, what we also do not know is what effect contemporary history education, with its supposed emphasis on inquiry and historiography, has on the historical consciousness and the political and social activities of modern citizens of Argentina. Across both periods, and at a time when Argentina has revived the Malvinas issue on the 30th anniversary of the 1982 war, we also have no idea how these contrasting approaches to history education fit into the broader context of recent and current national historical consciousness as applied to social and political action.

\subsection{Northern Ireland}

Northern Ireland is about to enter a decade that will commemorate The Easter Rising, Ireland's role at the Somme, Partition and the Civil War. The challenge facing history teachers therefore is an increasingly urgent one if only because the period commemorated defined the future of this troubled island for the next eighty years. NI, still a fragile society recovering from three decades of its most recent outbreak of brutal conflict, will be obliged yet again to face its divisive past and again these anniversaries will inevitably attract those wishing to use past events to promote exclusive and partisan interests.

The social and political implications of these kinds of commemorations are serious, for historians have persuasively argued that the furore caused by the 1966 Somme and Easter Rising remembrances were a significant focal point and a precursor for the most recent outbreak of the Troubles that began in 1969. It has been long recognised that in NI, events from the past have been used selectively in politicised ways to justify the contemporary political positions of one community and denigrate the beliefs and aspirations of the other [25].

We do not know, however, how history was actually taught in schools prior to 1968 . The prevailing view about that period, which acts as a clear stimulus for the kind of deeper investigation called for by this article, is that, prior to 1968, NI state (mainly Protestant) schools avoided Irish history in favor of English history and taught the former only at senior examination level and only when it impinged on the narratives of English history. In their separate way, Catholic schools followed these senior examination syllabi but without a prescribed curriculum in the junior years. It is suggested they had more freedom to pursue teaching that promulgated a nationalist view of Ireland's past [26].

To avoid a continuation of this separatist approach, recent history curriculum in NI adopted a process-led and inquiry-based approach, influenced by the UK's Schools History Project, a move that was formally recognised in the first statutory NI curriculum of 1989 [27]. However, subsequent research tentatively indicates that while this curriculum had its strengths, it also had serious limitations. While teachers wrestled with the complex pedagogical demands of teaching inquiry-based, 
multi-perspectival history they have been reluctant to raise contentious issues in case of adverse community reaction [28]. To date, there is still little substantive research evaluating the effectiveness of inquiry-based, multi-perspectival history teaching on students' learning in conflict environments and there has been no official NI evaluation of the 1989-2007 curriculum [28]. Even so, while some evidence shows that school students value the insights gathered in school history [29], analysis also shows that even if students are exposed to inquiry-based history, there is a tendency to use this knowledge selectively to support the dominant views of their respective communities [14]. Importantly, inquiry-based history in NI emphasises cognitive understanding yet the communal allegiances associated with national identity have deeply felt emotional associations. Having discovered these apparent tensions and issues in curriculum delivery, the 1989 NI curriculum remains an example of the model that is still advocated by the international community in other areas emerging from conflict.

\subsection{Australia}

History education in Australia in the 1950s and 1960s was didactic in approach and strongly traditionalist in content with a special focus on British imperial narratives and Australia's part within these narratives. In the 1970 s, reacting against what was considered a dry and conservative approach to history education, several state education departments, led by Tasmania, began slowly to move towards a social studies approach on the grounds of 'relevance'. Against that particular progressivist surge, teachers in New South Wales retained their discipline-based history focus, and, in the 1970s, began to employ UK Schools History project materials albeit on a localised school-by-school basis [30].

By the end of the 1970s, however, the generic social studies movement was growing in strength in Australia, reaching its apotheosis in 1989 in the Hobart Declaration that advocated the adoption of generic social education entitled Studies of Society and Environment or SOSE (there were local variations of nomenclature), with some educators professing a social action element in the SOSE curriculum. By the mid-1990s, all states and territories had adopted variations of SOSE with the exception of New South Wales, which, in secondary schools at least, retained history education.

We do not yet know what effect these transitions in history education pedagogy have had on historical consciousness in Australia during times of social and political upheaval. For example, in the 1970s, Australians were exercised by the issue of prohibited migration; the same concern applies today and is used as a wedge political issue by both sides of politics. We also do not know what response 1950s and early 1960s school students had to being taught British Imperial history and how this teaching affected their behavior as young adults in the 1960s and 1970s. Further, we do not know what levels of historical consciousness were acquired by school students in the 1990s in contrasting SOSE environments and in history-as-a-discipline environments, and how this affects their current worldview and their ideas about social action.

\section{Two Generations: The Importance of the Lived Experience}

A key element of this proposed methodology is a comparative analysis of two broad chronological stages in the lived experience of history education in the three chosen research sites. This would 
involve a substantial number of historically-based and ethnographically-framed interviews, initially with a representative sample of the generation now aged 45-60, to examine history education and its contexts in the late 1960s and 1970s when, across all three countries, history was still largely taught as a series of static canonical narratives but the level of socially disruptive contentious politics in the society at large was high.

The second component is an assessment of responses from subjects now aged in their 20s and 30 s to questions about the subsequent, consequent and current changing nature of the relationship between history education, identity politics and historical consciousness in all three countries during the period of transition to more progressive teaching methods. The latter investigation reflects the impact of school history education at a time when the stability of social and political consensus in Argentina and Northern Ireland remains brittle and when there has been a resurgence of strong divergences of view about 1970s-era social fragmentation issues in Australia.

\section{Dealing with History in the Present}

The need to know about how the history education/politics nexus functions is made all the more urgent for Australian educators when, for example, the Coalition shadow education minister Christopher Pyne and his colleagues have already promised to review, and potentially scrap, the proposed Australian history curriculum (with its world history perspectives) bringing back what Pyne's critics might describe as a traditionalist British imperial view of the past [31]. This move is reminiscent of former Prime Minister John Howard's 2006 attempt to introduce a traditionalist national history curriculum through a national summit that did not include the states and territories. This approach to history surfaced again on 27 September 2012 when, in his inaugural Sir Paul Hasluck address 'A Proper Sense of History' given at the University of Western Australia, Howard lamented a supposed lack of British imperial and Judeo-Christian perspectives in the 2010 draft Australian History Curriculum [32].

This paper has proposed a case and a methodology for testing the socially prevalent and largely implicit thesis that history education is an effective agent of forming social disposition. According to the research of Grever et al., history education in Australia, similarly to all modern nation states, has the seemingly insuperable task of managing the historico-cultural needs of a population where $27 \%$ of residents/citizens were born outside Australia [33] and where there is evidence that members of certain significant migrant populations have imported past and existing rivalries into their new home nation. These threats and challenges seem to encourage a nationalistic and monoculturalist approach to history education amongst some politicians and public commentators and simultaneously to mobilise the existing sectarian prejudices of a wide range of different communities, both of Australian and foreign descent.

That being the case, our contention is that there is very little point in policy-makers continuing to propose politically engineered revisions of history education as an antidote to civil discord without further evidence-based and detailed understanding of how history education actually functions as a social and political agent in modern, multicultural societies. 


\section{References}

1. ABC News Online. As it happened: Violence erupts in Sydney over anti-Islam film. 16 September 2012. Available online: http://www.abc.net.au/news/2015/anti-us-protests-hitsydney/4263372 (accessed on 5 November 2012).

2. Donnelly, K. Counter Islamism with commitment to core values. The Australian, 17 September 2012.

3. Gutman, H. Historical Consciousness in Contemporary America. In Power and Culture: Essays on the American Working Class; Gutman, H., Berlin, I., Eds.; Pantheon Books: New York, NY, USA, 1987.

4. History Wars and the Classroom: Global Perspectives; Taylor, T., Guyver, R., Eds.; IAP: Charlotte, NC, USA, 2011.

5. Bolton, G. The Oxford History of Australia: Volume 5: 1942-1995. The Middle Way; OUP: Melbourne, Australia, 2005.

6. English, R. Irish Freedom: The History of Nationalism in Ireland; Pan Macmillan: London, UK, 2006.

7. Hodges, D.C. Argentina's 'Dirty War': An Intellectual Biography; University of Texas Press: Austin, TX, USA, 1991.

8. Tarrow, S. Power in Movement: Social Movements, Collective Action and Politics; Cambridge University Press: Cambridge, UK, 1994.

9. The Social Movement of Society: Contentious Politics for a New Century; Meyer, D.S., Tarrow, S., Eds.; Rowman \& Littlefield: Lanham, MD, USA, 1998.

10. Tilly, C.; Tarrow, S. Contentious Politics; Paradigm Publishers: Boulder, CO, USA, 2007.

11. Rosenzweig, R.; Thelen, D. The Presence of the Past: Popular Uses of History in American Life; Columbia University Press: New York, NY, USA, 1998; pp. 111-113, 168-169.

12. Ashton, P.; Hamilton, P. History at the Crossroads: Australians and the Past; Halstead Press: Sydney, Australia, 2010; pp. 51-62.

13. Körber Stiftung Foundation. The Long Shadow of World War II; Körber Stiftung Foundation: Hamburg, Germany, 2005.

14. Reilly, J.; McCully, A.W. Critical Thinking and History Teaching in a Contested Society: The Potential Influence of Social Cognitions. Presented at American Educational Research Association Annual Meeting, New Orleans, LA, USA, 7-11 April 2011.

15. Beyond the Canon: History for the 21st Century; Grever, M., Stuurman, S., Eds.; Palgrave Macmillan: London, UK, 2007.

16. Grever, M. In Search of Commonality, History and Plurality in Multicultural Classes. Presented at the Euroclio Annual Conference, Nijmegen, The Netherlands, 27 March 2010.

17. Grever, M.; Pelzer, B.; Haydn, T. High school students' views on history. J. Curric. Stud. 2011, 43, 207-229.

18. MacMillan, M. Dangerous Games: The Uses and Abuses of History; Modern Library Edition, Random House: New York, NY, USA, 2009; pp. 73-78. 
19. Zajda, J. Transforming Images of Nation Building: Ideology and Nationalism in History School Textbooks in Putin's Russia, 2001-2010. In History Wars and the Classroom: Global Perspectives; Taylor, T., Guyver, R., Eds.; IAP: Charlotte, NC, USA, 2011; pp. 125-142.

20. Dreaming of a caliphate; Islam's philosophical divide. The Economist, 6 August 2011, Volume 400, 22.

21. De Vos, M. The return of the canon: Transforming Dutch history teaching. Hist. Workshop J. 2009, 67, 111-124.

22. Smith, A.; Vaux, T. Education, Conflict and International Development; UK Department of International Development: London, UK, 2003.

23. Oszlak, O. La Formación del Estado Argentina (The Formation of the Argentine State); Planeta: Buenos Aires, Argentina, 1997.

24. Bertoni, L.A. Construir la nacionalidad: Héroes, estatuas y fiestas 1887-1891 (Construction of the nation: Heroes, statues and commemorations). Boletin del Instituo de Historia Argentina y Americas 1992, 3, 77-111.

25. Walker, B. Dancing to History's Tune: History, Myth and Politics in Ireland; Institute of Irish Studies, The Queen's University of Belfast: Belfast, NI, UK, 1996; pp. 57-74.

26. Murray, D. Worlds Apart: Segregated Schools in Northern Ireland; Appletree Press: Belfast, NI, UK, 1985.

27. Department of Education Northern Ireland. The Northern Ireland Curriculum History: Programmes of Study and Attainment Targets; Her Majesty's Stationery Office: Belfast, NI, UK, 1991.

28. McCully, A. Northern Ireland: Taking History Education Forward in a Divided Society. In History Education under Fire: Textbooks and Curricula in International Perspective; Lassig, S., Repoussi, M., Cajani, L., Eds.; Georg Eckert Institute for International Textbook Research: Braunschweig, Germany, forthcoming.

29. Barton, K.; McCully, A. Secondary students' perspectives on school and community history in Northern Ireland. Teach. Coll. Rec. 2010, 112, 142-181.

30. Taylor, T. Under Siege from Left and Right: A Tale of the Australian School History Wars. In History Wars and the Classroom: Global Perspectives; Taylor, T., Guyver, R., Eds.; IAP: Charlotte, NC, USA, 2011; pp. 25-50.

31. Harrison, D.; Patty, A. Coalition would scrap the curriculum, The Age, 31 January 2011.

32. Howard, J. A Proper Sense of History. Sir Paul Hasluck Foundation Inaugural Lecture, presented at University of Western Australia. 27 September 2012. Available online: http://resources.news. com.au/files/2012/09/27/1226482/801957-sir-paul-hasluck-foundation-inaugural-lecture.pdf (accessed on 1 November 2012).

33. Australian Bureau of Statistics. 2011 Census data. Available online: http://abs.gov.au/ausstats/ abs@.nsf/Lookup/2071.0main+features90201013 (accessed on 1 November 2012).

(C) 2012 by the authors; licensee MDPI, Basel, Switzerland. This article is an open access article distributed under the terms and conditions of the Creative Commons Attribution license (http://creativecommons.org/licenses/by/3.0/). 